\title{
The Effects of International Financial Reporting Standards on Financial Reporting Quality
}

\author{
By Wafaa Salah ${ }^{*}$ \& Abdallah Abdel-Salam ${ }^{\dagger}$
}

The purpose of this study is to investigate whether the financial reporting under International Financial Reporting Standards (IFRS) has more quality than local GAAP for firms listed on Taiwan stock exchange. Financial Reporting Quality is measured in this study by three attributes of earnings introduced in previous literature, namely: 1) earnings management expressed as managing towards positive earnings and earnings smoothing and, 2) timely loss recognition expressed as the asymmetric incorporation of economic gains and losses and large negative net income, and 3) value relevance. Ordinary Least Square (OLS) Regression analysis, Ztest, and Binary Logistic Regression are employed to investigate the pre-IFRS (20082010) and post-IFRS (2012-2014) adoption periods on value relevance, earnings management, and timely loss recognition. The study employs a sample of 426 manufacturing firms from 8 industries listed on Taiwan stock exchange. The study finds that firms adopting IFRS evidence less earnings smoothing. However, there is no significant difference in either the timely loss recognition or the value relevance of accounting information between the pre and post-adoption periods. This study contributes to the literature by using data from an emerging market. It provides an insight to practitioners, international standard setters and regulators into the international debate on the effects of the switch from local GAAP to IFRS on Financial Reporting Quality.

Keywords: Emerging market, earnings management, timely loss recognition, value relevance.

\section{Introduction}

Investors around the world became suspicious about the quality of accounting information due to corporate financial scandals resulting from fraudulent financial reporting. They seek to have high quality, transparent and comparable financial information to help in making rational investment decisions. The Financial Reporting Quality (FRQ) is influenced by high-quality accounting standards and its appropriate enforcement (Benyasrisawat 2011, Khanagha 2011). Therefore, moving toward harmonized high-quality accounting standards is becoming an

"Lecturer of Accounting, The British University in Egypt, Egypt.

${ }^{\dagger}$ Professor of Accounting, Cairo University, Egypt.

https://doi.org/10.30958/ajbe.5-3-3

doi=10.30958/ajbe .5-3-3 
increasingly important issue to enhance the transparency and comparability of financial information produced.

Since 2001, the International Accounting Standards Board (IASB) an independent, non-profit organization has played an important role by developing highquality International Financial Reporting Standards (IFRS) for use internationally for financial reporting purposes. Its main objective is to achieve international convergence. The European Union's publicly listed firms are required to prepare their financial reports in accordance with IFRS. Taiwan adopted IFRS in 2012 and many other developing and developed countries have either adopted IFRS or are in the process of the adoption. Approximately 140 countries around the world have now permitted IFRS adoption (Dayanandan et al. 2016).

IASB does not provide a clear definition of FRQ. However, Financial Accounting Standards Board Statement of Financial Accounting Concepts No. 1 (1978) states that "one objective of financial reporting is to help present and potential investors in making rational investment decisions and in assessing the expected firm cash flows". Verdi (2006) defines FRQ as the accuracy with which financial reporting provides information to investors about the firm's activities, particularly its expected cash flows. While Dechow et al. (2010) define as "Higher quality earnings provide more information about the features of a firm's financial performance that are relevant to a specific decision made by a specific decision-maker".

Researchers are investigating the effect of IFRS on FRQ. Some research shows that adopting IFRS enhances FRQ in developed economies (Iatridis 2010, Jeanjean and Stolowy 2008, Zéghal et al. 2011). However, the benefit to emerging markets still unclear (Zhou et al. 2009). Other researchers show mixed results (Morais and Curto 2008, Paglietti 2010). On the other hand, some researchers show that adopting IFRS may not satisfy the information needs of stakeholders and has negative effects on the performance of the stock market and the trading volume (Ball 1995, Barth et al. 1999, Bradshaw and Miller 2002, Yoon 2007). It has been argued that FRQ is highly influenced by the opportunistic behavior of managers and national institutional factors (Jeanjean and Stolowy 2008, Palacios et al. 2014). The principle-based orientation of IFRS could add volatility to financial statements and open the door for possible managerial manipulation (Ahmed et al. 2013).

The empirical evidence about the benefit of implementing IFRS is conflicting and controversial. IFRS has been developed without regard for differences in socioeconomic and political environments between different countries. As a result, more empirical evidence on whether the adoption of IFRS in emerging markets has enhanced the FRQ regarding timely loss recognition, value relevance and the level of earnings management is needed. It is important to focus on these three metrics in emerging markets because IFRS is a principle-based approach which is characterized by greater flexibility for manipulation of accounting information. This provides managers the opportunity to manage earnings due to the encouragement of professional judgment and discretion. According to Wong and Jian (2003), the 
emerging market experience more earnings management because of the relatively weak investor protection and legal system.

The purpose of this study is to empirically investigate whether the adoption of IFRS leads to higher FRQ for manufacturing firms listed on the Taiwan stock exchange. The classification of Taiwan as an emerging market is based on the classification of the World Bank in 2018. It exhibits the characteristics of an emerging economy due to its weak corporate governance, poor legal enforcement and inadequate shareholder protection (Huang and Shiu 2009). According to IFRS 1, Taiwanese listed firms were required to issue their 2012 financial statements under both IFRS and Taiwanese GAAP which provides a unique opportunity to investigate this issue. According to Financial Supervisory Commission (2018), All firms listed on Taiwan stock exchange and financial institutions supervised by the Financial Supervisory Commission were required to apply IFRS starting from 2012 except unlisted public firms, insurance intermediaries, credit card firms and credit cooperatives. They were required to apply IFRS starting from 2015 (permitted from 2013).

Our empirical results show that firms in the post-IFRS period experienced lower level of earnings smoothing compared to firms in the pre-IFRS period. However, there is no evidence found that firms in the post-IFRS period evidenced more timely loss recognition or more value relevance of accounting information than in the pre-IFRS period. In particular, firms in the post-IFRS period have a higher variance of the change in net income and a less negative correlation between accruals and cash flows. This may suggest a significant reduction in earnings smoothing and improvement in FRQ after the transition to IFRS. This study is complements the findings in the existing literature regarding the effects of IFRS on FRQ.

This study contributes to the literature in several ways. First, the effects of IFRS adoption on FRQ in emerging markets have not been widely studied (Kwon et al. 2017) and several emerging markets are in the process of adopting IFRS, such as Saudi Arabian, Egypt, India, Korea, and Malaysia. This study encompasses a sample of listed firms in Taiwan which is considered one of the emerging markets that have a significant influence on the world economy (Bekaert and Harvey 2017). Thus practitioners and international standard setters from other emerging markets can benefit from the results of this study. Second, existing empirical studies have focused on developed countries, such as Germany, Australia, the UK, and France (Peng and Chen 2014, Kaaya 2015, Kwon et al. 2017). This study fills the gap of the related literature by shedding the light on emerging markets. Third, the costs and benefits of switching from local GAAP to IFRS are still unclear. This study provides empirical evidence that compares the FRQ under IFRS with that under local GAAP and this can benefit regulators as they try to make rational decisions regarding the adoption by publicly listed firms in emerging markets. Finally, the findings of this study may help analysts and investors understand IFRS and FRQ issues in emerging markets. This study follows Barth et al. (2008) and Zhou et al. (2009) in focusing on three metrics of FRQ: 1) value relevance, 2) earnings management, and 3) timely loss recognition. 
The remainder of this paper is organized as follows. Section 2 presents the related literature and develops the hypotheses. Section 3 deals with the sample selection, descriptive statistics of variables and the research methodology. Section 4 presents the empirical findings and Section 5 concludes the study.

\section{Literature Review and Hypothesis Development}

The quality of financial reporting is determined by the usefulness of information provided to meet the needs of users. One of the factors that affects FRQ is the accounting standards. High accounting standards are characterized by providing relevant, reliable, comparable and consistent accounting information (Khanagha 2011). Firms experience positive returns with increases in FRQ (Armstrong et al. 2010), a reduction in the cost of equity capital in countries with strong legal system (Li 2010), and increases the demand for equities by institutional investors (Florou and Pope 2012). Hence, literature tries to assess the effect of accounting standards on the quality of financial information.

Prior research measures FRQ in different ways. The majority of studies use value relevance, timely loss recognition, and earnings management as three main measures for FRQ as they provide useful financial information to stakeholders especially users in the equity market (Ahmed et al. 2013, Barth et al. 2008, Istrate et al. 2015, Jeanjean and Stolowy 2008, Morais and Curto 2008, Mousa and Desoky 2014, Paglietti 2010). Francis et al. (2004) consider seven measures of accounting quality, namely, earnings management, persistence, predictability, smoothness, value relevance, timeliness, and conservatism. On the other hand, Benyasrisawat (2011) points out three dimensions of FRQ, namely, earnings persistence, value relevance and earnings timeliness. This study uses three attributes of earnings introduced in previous literature (Barth et al. 2008, Kaaya 2015, Lin et al. 2012, Mousa and Desoky 2014, Peng and Chen 2014, Zhou et al. 2009). The attributes are 1) value relevance, 2) timely loss recognition expressed as the asymmetric incorporation of economic gains and losses and large negative net income, and, 3) earnings management expressed as managing towards positive earnings and earnings smoothing.

Paglietti (2010) defines earnings management as the management intention to mislead stakeholders about the financial position of the firm which may affect their compensation. He adds that higher quality of accounting information is characterized by low earnings management. On the other hand, value relevance studies are concerned about the evaluation of the relationship between accounting information and capital market values (Khanagha 2011). It is argued that higher quality of accounting information exhibits a strong relationship between earnings and returns (Mousa and Desoky 2014). Outa (2011) defines timely loss recognition as "the firm's ability to recognize losses as they occur by not engaging in activities that reschedule the losses over other periods of time". Coelho et al. (2017) argue that more timely 
recognition of the incurred losses in earnings make financial reporting more informative to investors and decision makers.

Several studies have tried to study the impact of adopting IFRS. Studies carried in developed countries regarding the higher quality of IFRS information reveals contradicting results. On the positive side, Irvine and Lucas (2006) find that IFRS has increased foreign direct investment, improve FRQ and enhance global market integration. Using a sample of 327 firms from 21 countries, Barth et al. (2008) find that firms exhibit less earnings management, higher frequency of large losses, an insignificant frequency of small positive earnings, and more value relevance of FRQ after voluntarily switching to IFRS. Similarly, the findings of Iatridis (2010) suggest that the implementation of IFRS in the UK decrease earnings management, lead to more value relevant accounting measures and more timely loss recognition which help investors in making more rational decisions. These two studies provide consistent results and suggest that adopting IFRS reinforces information reporting quality. Moreover, an empirical study by Armstrong et al. (2010) document that the adoption of IFRS in the European stock market improved the information transparency and earnings quality. Using a longitudinal study that covers pre-IFRS and post-IFRS periods during 1990-2008 for publicly listed Australian industrial firms, Chalmers et al. (2011) find that earnings become more value-relevant and suggest that IFRS adoption affects the associations between accounting information and market value. Several studies have confirmed that adopting IFRS has increased FRQ (Chalmers et al. 2011, Devalle et al. 2010, Meeks and Swann 2009, Chan et al. 2015).

Other studies report contradicting results. A study by Van Tendeloo and Vanstraelen (2005) suggest that there is no significant difference in FRQ for firms adopting IFRS compared to firms adopting German GAAP. Similarly, using a sample of German firms applying IFRS since 2005, Lin et al. (2012) suggest a decline in FRQ under IFRS. They find that financial reports evidence less value relevance, less timely loss recognition, and more earnings management compared to those firms applying U.S. GAAP. These two studies provide consistent results and suggest that adopting IFRS does not enhance information reporting quality. Both Ahmed et al. (2013) and Christensen et al. (2015) find that European Union firms experience more earnings management after IFRS adoption. Ahmed et al. (2013) argue that firms that have voluntary application to IFRS experience less earnings management due to having incentives to increase the transparency of their reporting and attract market capital. On the other hand, firms that have mandatory application to IFRS, lack the motivation to have a transparent financial report which leads to higher earnings management after the adoption of IFRS. However, Capkun et al. (2016) conducted a study in 30 countries and found that firms adopting early, late or mandatory IFRS experience an increase in earnings management. They concluded that the principlebased nature of IFRS allows for greater flexibility in selecting accounting methods and greater discretion in earnings measurement which lead to an increase in earnings management. The conflicting results between the two studies may be due to differences in sample selection where Ahmed et al. (2013) sample include only 
developed countries (European Union) while Capkun et al. (2016) sample includes both developed and developing countries which have a different legal system, capital market maturity, and development.

The studies presented above are applied in developed countries where we could expect an improvement in FRQ after IFRS adoption due to strong investor protection, strong legal enforcement, and capital market maturity. However, the results are mixed which makes it difficult to reach a general conclusion that IFRS enhance FRQ in developed countries. This result is supported by Nulla (2014) who observed that each country implemented the same accounting standards in a different way due to flexible standards which can lead to a reduction in FRQ even in strong enforcement countries like Germany and France.

Regarding the developing countries, Aljifri and Khasharmeh (2006) investigated the benefits of IFRS to the United Arab Emirates (UAE). They found that there is a general agreement among different users as investors, auditors and creditors on the importance of applying IFRS in the UAE. Similarly, Liu et al. (2011) examined the effect of IFRS on FRQ for publicly listed firms in China and find significant improvement expressed as an increase in value relevance of accounting information and a reduction in earnings smoothing. In a two emerging counties study, Khanagha (2011) investigated the value relevance of accounting information under IFRS in Bahrain for the period 1996-2008 and the United Arab Emirates for the period 20012008 listed firms. A comparison of the results for the pre and post-IFRS adoption, shows more relevant accounting information after the adoption of IFRS in Bahrain stock market, while there was a decline in value relevance for United Arab Emirates stock market. Using a sample of 117 listed firms in Indonesia Stock Exchange, Arum (2013) examined the impact of IFRS on the FRQ which are measured by the proxy of value relevance, timely loss recognition, and earnings management of accounting information. The empirical results indicate lower earnings management and higher value relevance of accounting information while having no effect on the timely loss recognition. This may signal an improvement in the financial reporting quality.

On the other hand, other studies show that adopting IFRS in developing countries does not necessarily lead to an improvement in FRQ. Chen and Yeh (2002), employing a sample of Chinese firms, examined the effect of adopting IFRS on FRQ. Their study revealed that IFRS does not improve accounting practices due to family ownership, informal personal relationship and political influences which contribute to the low reporting quality. Similarly, Rudra and Bhattacharjee (2012) find that publicly listed Indian firms using IFRS experience more earnings management compared to Indians firms using local GAAP which may be considered as a signal to the regulators to think about the effectiveness of IFRS in emerging markets suffering from weak investor protection and legal enforcement. Ames (2013), using data of 3950 listed companies in South Africa between 2000 to 2011 examined the impact of adopting IFRS on FRQ. He finds that FRQ is not improved among the firms adopting IFRS. A study of Taiwanese firms by Peng and Chen (2014) showed that the quality of the financial reports under local GAAP provides more value relevant than IFRS. Other 
empirical studies find mixed results (Clarkson et al. 2011, Houqe et al. 2012, Outa 2011, Paananen and Lin 2009).Despite, the argument that IFRSs may not fit developing countries due to weak investor protection and legal enforcement (Kaaya, 2015). It is clear that some studies presented show that IFRS improves FRQ. This result is supported by Karampinis and Hevas (2009) who concluded that mandating IFRS may prove beneficial even in an unfavorable context.

Based on the above discussion, this study aims to compare the FRQ under local GAAP with that under IFRS by examining the impacts of implementing IFRS in one of the emerging markets. The study will fill the gap of the related literature by adding more evidence regarding emerging markets. Based on the above discussion that show conflicting evidence on the effect of IFRS on FRQ, the following hypotheses are formulated:

H1: Firms using IFRS experience less earnings management compared to firms using local GAAP.

H2: Firms using IFRS experience more timely recognition of losses compared to firms using local GAAP.

H3: Firms using IFRS experience more value relevant accounting information compared to firms using local GAAP.

\section{Methodology}

In this section, three FRQ that has been suggested in prior research as potentially important will be considered: value relevance, timely loss recognition, and earnings management. They are examined separately by comparing accounting information prepared under Taiwanese GAAP from 2008 to 2010 with those prepared under IFRS from 2012 to 2014. Quantifying FRQ is difficult, Hence, this study follows Lang et al. (2006), Barth et al. (2008) and Zhou et al. (2009) in focusing on a range of FRQ measures. According to Lang et al. (2006), accruals are sensitive to the industry in which the firm operates. Accordingly, the effect of industry on the characteristics of accounting data was considered in this study.

\section{Earnings Management}

This study analyzes two measures of earnings management. The first relates to the examination of earnings smoothing and the second focuses on managing towards positive earnings.

\section{Earnings smoothing}

To test for changes in earnings smoothing, three different measures are used in this study. 
1-First, the variability of the changes in the annual net income deflated by end of year total assets. Earnings should fluctuate over time if firms do not use accruals to manage earnings. Accordingly, lower values of the variance of the change in net income are considered a signal to higher earnings smoothing, and vice versa. The change in net income can be affected by factors other than the financial reporting. Hence, controls from prior research have been used as shown in the below model(Barth et al., 2008, Lang et al., 2006):

$\Delta N I=\beta 0+\beta 1$ SIZE $+\beta 2$ GROWTH $+\beta 3$ EISSUE $+\beta 4$ LEV $+\beta 5$ DISSUE $+\beta 6$ TURN $+\beta 7 C F+\beta 8$ AUD $+\beta 9$ XLIST + $\beta 10$ NUMEX + $\beta 11$ SECTOR1 + $\beta 12$ SECTOR $2+\beta 13$ SECTOR3 $+\beta 14$ SECTOR $+\beta 15$ SECTOR5 $+\beta 16$ SECTOR6 $+\beta 17$ SECTOR7 $+\beta 184 N I(-1)+\varepsilon$

Where $\triangle \mathrm{NI}$ is the annual change in net income, SIZE is the natural logarithm of the end of year market value of equity, GROWTH is the annual change in sales, EISSUE is the annual change in common stock, LEV is end of year total liabilities divided by equity book value, DISSUE is annual change in total liabilities, TURN is sales divided by end of year total assets, $\mathrm{CF}$ is annual net cash flow from operating activities divided by end of year total assets, AUD is an indicator variable that equals one if the firm's auditor is PwC, KPMG, E\&Y or D\&T and zero otherwise, XLIST is an indicator variable that equals one if the firm is listed outside the EU, NUMEX is the number of Stock Exchanges on which a firm's stock is listed. SECTOR1 is the Commodity Chemicals industry, SECTOR2 Iron \& Steel industry, SECTOR3 is the Auto, Truck \& Motorcycle Parts industry, SECTOR4 is the Textiles \& Leather Goods industry, SECTOR5 is the Food Processing industry, SECTOR6 is the Construction \& Engineering industry, SECTOR7 is the Electrical Components \& Equipment industry and Machinery \& Equipment is the reference category. $\Delta \mathrm{NI}(-1)$ is a lagged value of observed endogenous response variables for solving serial autocorrelation issue. $\varepsilon$ is the error term.

The residuals of the regression of model 1 are denoted as $\Delta \mathrm{NI}^{*}$ and their standard deviation $\sigma_{\Delta \mathrm{Ni}^{*}}$. Lower standard deviation could be considered as evidence of using accruals to smooth earnings.

2- Second, the variability of annual changes in net income relative to the variability of annual changes in cash flows. The variability of annual changes in cash flows is the variance of the residuals of the regression of annual change in cash flow. Despite the controls used in model 1 , the variability in net income may be due to activities that are not correlated with discretionary accruals (Lin et al. 2012). Examining the variability of annual changes in net income relative to the variability of annual changes in cash flows control this concern as firms with more variability in cash flows will have more variability in net income. Controls have been used to mitigate the effect of other factors as shown in the below model: 
$\Delta \mathrm{CF}=\beta 0+\beta 1 \mathrm{SIZE}+\beta 2 \mathrm{GROWTH}+\beta 3$ EISSUE $+\beta 4 \mathrm{LEV}+\beta 5$ DISSUE $+\beta 6$ TURN + $\beta 7$ AUD $+\beta 8$ XLIST + $\beta 9$ NUMEX $+\beta 10$ SECTOR $1+\beta 11$ SECTOR $2+$ $\beta 12$ SECTOR $3+\beta 13$ SECTOR $4+\beta 14$ SECTOR $5+\beta 15$ SECTOR $6+\beta 16$ SECTOR $7+$ $\beta 17 \Delta \mathrm{CF}(-1)+\varepsilon$

Where $\triangle \mathrm{CF}$ is the annual change in net operating cash flow and the residuals of the regression of model 2 are denoted as $\Delta \mathrm{CF}^{*}$. The second metric is concerned about the variability of $\Delta \mathrm{Ni}^{*} / \Delta \mathrm{CF}^{*}$ over the pre-IFRS (2008-2010) and post-IFRS (2012-

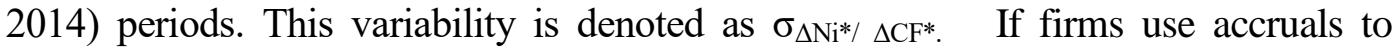
smooth earnings, the variability of net income will be less than that cash flow.

3- Finally, the correlation between total accruals (ACC) and operating cash flows (CF) helps in detecting the smoothing effect of accruals. If managers use accruals to smooth earnings, there will be a negative correlation between them as managers may tend to increase accruals when suffering from shortage in cash flows(Ball and Shivakumar 2005, Paglietti 2010, Myers et al. 2007). Again, to control for the effect of other factors, the following regression models are used:

$\mathrm{CF}=\beta 0+\beta 1 \mathrm{SIZE}+\beta 2 \mathrm{GROWTH}+\beta 3 \mathrm{EISSUE}+\beta 4 \mathrm{LEV}+\beta 5 \mathrm{DISSUE}+\beta 6$ TURN $+\beta 7$ AUD $+\beta 8$ XLIST $+\beta 9$ NUMEX $+\beta 10$ SECTOR $1+\beta 11$ SECTOR2 + $\beta 12$ SECTOR $3+\beta 13$ SECTOR4 + $\beta 14$ SECTOR $5+\beta 15$ SECTOR6 + $\beta 16$ SECTOR7 + $\beta 17 \mathrm{CF}(-1)+\varepsilon$

$A C C=\beta 0+\beta 1$ SIZE $+\beta 2$ GROWTH $+\beta 3$ EISSUE $+\beta 4$ LEV $+\beta 5$ DISSUE $+\beta 6$ TURN $+\beta 7$ AUD $+\beta 8$ XLIST + $\beta 9$ NUMEX $+\beta 10$ SECTOR $1+\beta 11$ SECTOR $2+$ $\beta 12$ SECTOR $3+\beta 13$ SECTOR4 + $\beta 14$ SECTOR5 + $\beta 15$ SECTOR $6+\beta 16$ SECTOR7 + $\beta 17 \mathrm{ACC}(-1)+\varepsilon$

Where $\mathrm{ACC}$ is net income (NI) minus $\mathrm{CF}$. The residuals of the regression in model 3 are denoted as $\mathrm{CF}^{*}$ and the residuals of the regression in model 4 are denoted as $\mathrm{ACC}^{*}$. The third metric is concerned about the correlation between $\mathrm{CF}^{*}$ and ACC $^{*}$. The higher negative correlation between them signals the use of accruals to smooth variability in earnings and thus affect FRQ (Myers et al. 2007).

\section{Managing Towards Positive Earnings}

The second earnings management measure tests if firms manage earnings towards small positive earnings (denoted as SPOS) rather than a negative earnings. According to Kwon et al. (2017), managers tend to smooth earnings to avoid losses which may results in more frequent positive earnings, if possible, compared to small losses. Hence, a high frequency of small positive earnings signals the greater management's discretion to avoid losses and thus affect FRQ. This measure is evaluated by estimating the coefficient of a dummy variable SPOS in the following logistic regression model(Barth et al. 2008): 
$\operatorname{POST}(0,1)=\beta 0+\beta 1 \mathrm{SPOS}+\beta 2 \mathrm{SIZE}+\beta 3 \mathrm{GROWTH}+\beta 4 \mathrm{EISSUE}+\beta 5 \mathrm{LEV}+\beta 6$

DISSUE $+\beta 7$ TURN $+\beta 8 \mathrm{CF}+\beta 9$ AUD $+\beta 10$ XLIST $+\beta 11$ NUMEX $+\varepsilon$ (5)

$\operatorname{POST}(0,1)$ is a dummy variable that equals one for firms adopting IFRS and zero for firms adopting local GAAP. SPOS equals one if the net income deflated by total assets is between 0 and 0.01 and zero otherwise (Barth et al. 2008). This measure is concerned about the coefficient of SPOS in the regression equation. If the coefficient is negative, this means that firms in the pre-IFRS period are more likely to smooth earnings toward small positive net income compared to firms in the post-IFRS period and vice versa.

\section{Timely Loss Recognition}

Timely loss recognition is the second FRQ measure which reflects accounting conservatism. Ball et al. (2000) define timeliness as "the degree to which accounting income incorporates economic income". It can be assessed by two metrics. The first one focuses on the likelihood of reporting a large negative net income (denoted as LNEG). Higher FRQ is characterized by recognizing large losses as they occur rather than being deferred to future periods (Zhou et al. 2009). If managers smooth earnings, large losses should be relatively rare. Hence, high frequency of timely loss recognition signals better FRQ. The following logistic regression is constructed to estimate the likelihood of loss recognition timeliness (LNEG) following IFRS adoption (Lang et al. 2006):

$\operatorname{POST}(0,1)=\beta 0+\beta 1 \mathrm{LNEG}+\beta 2 \mathrm{SIZE}+\beta 3 \mathrm{GROWTH}+\beta 4 \mathrm{EISSUE}+\beta 5 \mathrm{LEV}+$ $\beta 6$ DISSUE $+\beta 7$ TURN $+\beta 8 \mathrm{CF}+\beta 9$ AUD $+\beta 10$ XLIST $+\beta 11$ NUMEX $+\varepsilon$

LNEG is a dummy variable that equals one if the net income scaled by total assets is lower than -0.20 and zero otherwise (Barth et al. 2008). This measure is concerned about the coefficient of LNEG in the regression equation. If the coefficient is positive, this means that firms in the post-IFRS period are more likely to recognize large losses in a timely manner compared to firms in the pre-IFRS period and vice versa.

The second measure of timely loss recognition is concerned about the asymmetric incorporation of economic gains and losses. Appropriate loss recognition compared to profit recognition has been used in prior research to estimate FRQ (Ahmed et al. 2013). The stock returns are used as a proxy for good and bad news and measured by $\mathrm{R}^{2}$ of the return-earnings regression model proposed by Basu (1997):

$$
\operatorname{Def}(E)=\beta 0+\beta 1_{(\operatorname{Def}(E))} D r^{-}+\beta 2_{(\operatorname{Def}(E))} r+\beta 3_{(\operatorname{Def}(E))}\left(D r^{-} \cdot r\right)+\varepsilon_{(\operatorname{Def}(E))}
$$


Where $\operatorname{Def}(\mathrm{E})$ is earnings per share in year $\mathrm{t}$ deflated by stock price per share in year t-1. Dr is a dummy that takes value one in case of bad news( if $r<0$ ) and zero otherwise and $\mathrm{r}$ is annual stock returns from six months after the firm's fiscal year-end. The interaction between $D r^{-}$with $r(\beta 3)$ shows the incremental effect of bad news relative to good news on earnings. According to Lang et al. (2006), the information in earnings will find its way into the share price, so the concern is whether the news is captured in earnings in a timely manner. FRQ is associated with share price, therefore a higher $\mathrm{R}^{2}$ indicates higher reporting quality. In addition, this measure is concerned about the magnitude of the coefficient of the interaction between Dr with $r(\beta 3)$ in the regression equation. The large coefficient is a signal of more timely loss recognition.

\section{Value Relevance}

Following previous studies, this study measures value relevance using the price-earnings model (Collins et al. 1999, Van der Meulen et al. 2007). Value relevance considers that high-quality financial reporting should have a high degree of association with the firm's share price which provides more useful information to investors. The model distinguishes between positive and negative earnings as follows (Ohlson 1995):

$\mathrm{P}_{\mathrm{it}}=\beta 0+\beta 1 \mathrm{X}_{\mathrm{it}}+\beta 2 \mathrm{DX}+\beta 3 \mathrm{X}_{\mathrm{it}} * \mathrm{DX}+\beta 4 \mathrm{BV}_{\mathrm{i}, \mathrm{t}-1}$

Where $P_{i t}$ is the share price three months after fiscal year end $t, X_{i t}$ is earnings per share, DX is a dummy variable equal to one if earnings are negative or zero otherwise and $\mathrm{BV}_{\mathrm{i}, \mathrm{t}-1}$ is the book value per share at the beginning of period $\mathrm{t}$, It should be noted that the coefficient of earnings, $\beta 1$, reflects the pricing effect of current earnings. The measure of value relevance is based on the adjusted $R^{2}$ of the model which examines the explanatory power of accounting information over years (Wu et al., 2017).

\section{The Sample}

Taiwanese publicly listed firms have been required to switch from the Taiwanese GAAP to IFRS in 2012. A sample of 426 firms listed on Taiwan stock exchange is randomly selected in this study. Table 1 presents the sample industry breakdown. The sample comprises a range of industries in the manufacturing sector. Data is obtained from Thomson Reuters DataStream database covering six years, pre-IFRS (2008-2010) and post-IFRS (2012-2014). The same set of 426 firms adopted Taiwanese GAAP in the pre-IFRS (2008-2010) and IFRS in the post-IFRS (2012-2014) period. 
Table 1. Industry Analysis

\begin{tabular}{|l|c|c|c|c|}
\hline Industry & Frequency & Percent & Valid Percent & $\begin{array}{c}\text { Cumulative } \\
\text { Percent }\end{array}$ \\
\hline $\begin{array}{l}\text { Auto, Truck \& } \\
\text { Motorcycle Parts }\end{array}$ & 198 & 5.2 & 5.2 & 5.2 \\
\hline $\begin{array}{l}\text { Commodity } \\
\text { Chemicals }\end{array}$ & 387 & 10.1 & 10.1 & 15.3 \\
\hline $\begin{array}{l}\text { Construction \& } \\
\text { Engineering }\end{array}$ & 225 & 5.9 & 5.9 & 21.1 \\
\hline $\begin{array}{l}\text { Electrical } \\
\text { Components \& } \\
\text { Equipment }\end{array}$ & 1521 & 39.7 & 39.7 & 60.8 \\
\hline Food Processing & 225 & 5.9 & 5.9 & 66.7 \\
\hline $\begin{array}{l}\text { Industry and } \\
\text { Machinery \& } \\
\text { Equipment }\end{array}$ & 549 & 14.3 & 14.3 & 81 \\
\hline $\begin{array}{l}\text { Iron \& Steel } \\
\text { industry }\end{array}$ & 270 & 7 & 7 & 88 \\
\hline $\begin{array}{l}\text { Textiles \& } \\
\text { Leather Goods }\end{array}$ & 459 & 12 & 12 & 100 \\
\hline Total & 3834 & 100 & 100 & \\
\hline
\end{tabular}

\section{Empirical Results and Analysis}

\section{Descriptive Statistics}

Table 2 presents descriptive statistics for the test and control variables used in the research design. Both have been examined separately under both local GAAP and IFRS for the same set of firms. Data is approximately symmetric as skewness ranges from -0.46 to 0.5 . The descriptive analysis of the test variables reveals that there is a slight decrease in the mean of the change in annual net cash flow (CF_DELTA) and accruals (ACC) under IFRS compared to Taiwanese GAAP. This may signal a decrease of earnings management practices under IFRS. However, there are no significant differences in the mean and dispersion of the other test variables under both local GAAP and IFRS.

As for control variables, the descriptive statistics show that the adoption of IFRS causes a significant reduction in the mean of the annual change in sales (GROWTH) from 355834 to -495997 . Moreover, a significant reduction in the mean of the annual change in common stocks (EISSUE) and the annual change in total liabilities (DISSUE) under IFRS. This may signal that firms in the pre-IFRS period are more likely to issue stocks and debt than firms in the post-IFRS period.

Table 3 reveals that the time series test and control variables are stationary at the 0.01 level. Table 4 shows that according to Schwarz criterion, there is a long-term equilibrium relationship among the time series variables where the p-value of both Tau-statistic and Z-statistic are at the 0.01 level. 
Table 2. Descriptive Statistics

\begin{tabular}{|c|c|c|c|c|c|c|c|c|c|c|}
\hline & \multicolumn{4}{|c|}{ Pre-IFRS (2008-2010) } & \multicolumn{6}{|c|}{ Post-IFRS (2012-2014) } \\
\hline & Mean & Median & Std. Dev. & Skewness & Kurtosis & Mean & Median & Std. Dev. & Skewness & Kurtosis \\
\hline \multicolumn{11}{|c|}{ Test Variables } \\
\hline NI_DELTA & -0.003 & -0.002 & 0.012 & -0.04 & 2.23 & -0.002 & -0.002 & 0.011 & -0.09 & 2.33 \\
\hline CF_DELTA & 569943 & 440354 & 2731030 & 0.15 & 2.57 & 552444 & 485586 & 2782907 & 0.14 & 2.42 \\
\hline ACC & -3516552 & -2989165 & 2797312 & -0.55 & 2.39 & -3514471 & -3123636 & 2672059 & -0.46 & 2.43 \\
\hline DEF & 0.048 & 0.050 & 0.024 & -0.09 & 2.05 & 0.048 & 0.048 & 0.023 & -0.02 & 2.12 \\
\hline $\mathbf{R}$ & 0.037 & 0.031 & 0.152 & 0.14 & 1.89 & 0.045 & 0.038 & 0.132 & 0.20 & 2.26 \\
\hline $\mathbf{P}$ & 0.590 & 0.580 & 0.166 & 0.33 & 2.18 & 0.575 & 0.546 & 0.166 & 0.50 & 2.27 \\
\hline BV & 0.489 & 0.482 & 0.066 & 0.43 & 2.52 & 0.497 & 0.493 & 0.070 & 0.25 & 2.18 \\
\hline $\mathbf{X}$ & 0.031 & 0.030 & 0.018 & 0.28 & 2.25 & 0.031 & 0.028 & 0.019 & 0.44 & 2.27 \\
\hline \multicolumn{11}{|c|}{ Control Variables } \\
\hline LNSIZE & 18.042 & 17.998 & 1.196 & 0.12 & 2.58 & 18.216 & 18.087 & 1.131 & 0.22 & 2.63 \\
\hline GROWTH & 355834 & 228340 & 5927955 & 0.14 & 2.12 & -495997 & -648252 & 5419240 & 0.22 & 2.51 \\
\hline EISSUE & 1119962 & 1185916 & 1007546 & -0.20 & 2.08 & 539270 & 585250 & 1169628 & 0.19 & 1.76 \\
\hline LEV & 0.879 & 0.852 & 0.216 & 0.40 & 2.33 & 0.888 & 0.880 & 0.219 & 0.27 & 2.25 \\
\hline DISSUE & 1620513 & 1316895 & 3300458 & 0.12 & 2.32 & 814413 & 366747 & 3287520 & 0.52 & 2.65 \\
\hline TURN & 0.903 & 0.852 & 0.403 & 0.38 & 2.65 & 0.831 & 0.801 & 0.367 & 0.37 & 2.98 \\
\hline CF & 0.061 & 0.061 & 0.027 & -0.003 & 2.03 & 0.061 & 0.062 & 0.026 & -0.01 & 2.11 \\
\hline
\end{tabular}


Table 3. Unit Root Test

\begin{tabular}{|c|c|c|c|c|}
\hline Method & Statistic & Prob.** & Cross-sections & Obs \\
\hline \multicolumn{5}{|c|}{ Null: Unit root (assumes common unit root process) } \\
\hline Levin, Lin \& Chu t* & -71.0288 & 0.0000 & 16 & 20413 \\
\hline \multicolumn{5}{|c|}{ Null: Unit root (assumes individual unit root process) } \\
\hline $\begin{array}{l}\text { Im, Pesaran and } \\
\text { Shin W-stat }\end{array}$ & -63.7571 & 0.0000 & 16 & 20413 \\
\hline $\begin{array}{l}\text { ADF - Fisher Chi- } \\
\text { square }\end{array}$ & 2341.98 & 0.0000 & 16 & 20413 \\
\hline $\begin{array}{l}\text { PP - Fisher Chi- } \\
\text { square }\end{array}$ & 2606.64 & 0.0000 & 16 & 20432 \\
\hline
\end{tabular}

**Probabilities for Fisher tests are computed using an asymptotic Chi-square distribution. All other tests assume asymptotic normality.

Table 4. Tau and Z-statistics

\begin{tabular}{|l|c|c|c|c|}
\hline Dependent & tau-statistic & Prob.* $^{*}$ & Z-statistic & Prob.* $^{*}$ \\
\hline NETINCOME & -18.42707 & 0.0000 & -536.7976 & 0.0000 \\
\hline NI_DELTA & -16.62892 & 0.0000 & -454.5156 & 0.0000 \\
\hline LNSIZE & -12.56317 & 0.0000 & -422.3788 & 0.0000 \\
\hline GROWTH & -12.73522 & 0.0000 & -326.5989 & 0.0000 \\
\hline EISSUE & -17.43492 & 0.0000 & -487.8751 & 0.0000 \\
\hline LEV & -14.80203 & 0.0000 & -530.8698 & 0.0000 \\
\hline DISSUE & -18.41085 & 0.0000 & -535.3919 & 0.0000 \\
\hline TURN & -14.06258 & 0.0000 & -574.5237 & 0.0000 \\
\hline CF & -18.34584 & 0.0000 & -532.5232 & 0.0000 \\
\hline CF_DELTA & -19.47992 & 0.0000 & -585.8725 & 0.0000 \\
\hline ACC & -18.40662 & 0.0000 & -535.9143 & 0.0000 \\
\hline DEF & -17.04257 & 0.0000 & -473.4941 & 0.0000 \\
\hline R & -14.28235 & 0.0000 & -352.1540 & 0.0000 \\
\hline P & -22.03178 & 0.0000 & -704.3500 & 0.0001 \\
\hline BV & -20.40924 & 0.0000 & -628.7475 & 0.0000 \\
\hline X & -21.83900 & 0.0000 & -695.1914 & 0.0001 \\
\hline
\end{tabular}

\section{Earnings Management}

Table 5 presents the results for earnings management measures: managing towards positive earnings and earnings smoothing for firms adopting local GAAP from 2008 to 2010(pre-IFRS) and adopting IFRS from 2012 to 2014(post-IFRS). The first result, the test of the variability of $\Delta \mathrm{NI}^{*}$ suggests that earnings are less volatile for firms in the pre-IFRS period, 0.00834, than for firms in the post-IFRS period, .00941, after controlling for other factors. This difference is statistically significant at the 0.01 level which suggests a significant reduction in earnings smoothing and improvement in FRQ after the transition to IFRS. On the contrary, the second result, the ratio of the variance of change in net income, $\Delta \mathrm{NI}^{*}$ to the variance of change in cash flow, $\triangle \mathrm{CF}^{*}$ is lower for firms in the post-IFRS period, 0000001902, than for firms in the pre-IFRS period, 0.0000004745. Although this may suggest that the variability in net income for firms in the post-IFRS period is not due to the variability in cash flow but driven by the effect of accruals, it is not statistically significant. 
The third result indicates the correlation between cash flows and accruals. The correlation between $\mathrm{CF}^{*}$ and $\mathrm{ACC}^{*}$, for the pre-IFRS period, -0.54 , is significantly more negative than the post-IFRS period, -0.038 . There is a significant negative correlation between cash flow and accruals at the 0.05 level in the pre-IFRS period. This may suggest that management may use accruals to smooth earnings when cash flow is low. The negative correlation between accruals and cash flow decreased when moving from local GAAP to IFRS. This may indicate that firms adopting IFRS are less likely to use accruals to smooth earnings. This result is consistent with the first one which supports the increase in the quality of financial reports after the IFRS adoption. Finally, the regression coefficient of SPOS is negative which may indicate that firms in the post-IFRS period are less likely oriented towards reporting small positive earnings compared to pre-IFRS. However, the coefficient is insignificant. This indicates that there is no statistically significant difference between firms in the post and pre-IFRS period in managing earnings toward a target.

Table 5. Comparison of the Pre-IFRS and Post-IFRS Earnings Management

\begin{tabular}{|l|c|c|}
\hline Earnings Smoothing & PRE-IFRS $(\mathbf{N = 1 2 7 8 )}$ & POST-IFRS (N=913) \\
\hline Variability of $\Delta \mathbf{N I}^{*}$ & 0.00834 & $.00941^{* * *}$ \\
\hline $\begin{array}{l}\text { Variability of } \boldsymbol{\Delta} \mathbf{N I}^{*} \text { over } \\
\Delta \mathbf{C F}^{*}\end{array}$ & 0.0000004745 & .0000001902 \\
\hline $\begin{array}{l}\text { The correlation of CF* and } \\
\text { ACC*. }\end{array}$ & $-0.54^{* *}$ & -0.038 \\
\hline $\begin{array}{l}\text { Managing Towards Positive } \\
\text { Earnings }\end{array}$ & & \\
\hline Small Positive NI(SPOS) & Beta $=-0.61 \quad \operatorname{Exp}(\mathrm{B})=0.941$ \\
\hline
\end{tabular}

The symbols $* *, * * *$ indicate a significant difference between pre-IFRS and post-IFRS at the 0.05 and the 0.01 level respectively.

In summary, the above-mentioned results show that firms in the post-IFRS period and less likely to use accruals to smooth earnings compared to the pre-IFRS period. In addition, there are no statistically significant differences between firms in the pre and post-IFRS in the ratio of the variance of change in net income, $\triangle \mathrm{NI}^{*}$, to the variance of change in cash flow, $\Delta \mathrm{CF}^{*}$, and managing earnings toward a target. This result supports the first hypothesis which states that "Firms adopting IFRS are less likely to manage earnings compared to firms adopting local GAAP”.

\section{Timely Loss Recognition}

Table 6 presents the results for timely loss recognition: asymmetric incorporation of economic gains and losses and large negative net income. The negative coefficient indicates that firms in the post-IFRS period are less likely to report large losses. However, the coefficient of LNEG is insignificant. In another word, there is no significant difference between pre and post-IFRS in reporting large negative losses. Table 6 shows the $R^{2}$ of the regression equation of accounting earnings on stock returns for both good news and bad news. Earnings are regressed on annual stock returns, an indicator that represents bad news and the 
interaction of these two predictors. The $\mathrm{R}^{2}$ in the pre-IFRS is 0.5933 which is larger than that in the post-IFRS which is 0.4493. This indicates that earnings under local GAAP proportionally shows greater timeliness in presenting losses relative to gains. The magnitude of the coefficient of the interaction variable (B3) is significant under both local and IFRS GAAP although its magnitude is smaller in the pre-IFRS, -1.719491, compared to the post-IFRS, -1.425209 which is inconsistent with the $\mathrm{R}^{2}$ result. However, there is no significant difference between the two coefficients. This indicates that there is no significant difference between pre and post-IFRS in the timeliness of earnings which is consistent with the previous result.

Table 6. Comparison of the Pre-IFRS and Post-IFRS Timely Loss Recognition

\begin{tabular}{|l|c|c|}
\hline Timely Loss Recognition & PRE-IFRS $(\mathbf{N}=1278)$ & POST-IFRS (N=913) \\
\hline Large Negative Net & Beta $=-0.105$ & $\operatorname{Exp}(\mathrm{B})=0.901$ \\
Income(LNEG) & $\beta 1=0.354147 \#$ & $\beta 1=0.332621 \#$ \\
& $\mathrm{~B} 2=1.621350 \#$ & $\mathrm{~B} 2=1.617809 \#$ \\
Asymmetric Incorporation & $\mathrm{B} 3=-1.719491 \#$ & $\mathrm{~B} 3=-1.425209 \#$ \\
Of Economic Gains And & $\mathrm{R}^{2}=0.593385$ & $\mathrm{R}^{2}=0.449316$ \\
Losses & & \\
\hline
\end{tabular}

The symbols * $* * *$ indicate a significant difference between pre-IFRS and post-IFRS at the 0.1 and 0.01 level respectively. The symbol \# indicates significantly different from 0 at the 0.01 level.

In summary, the above-mentioned results show that there is no significant increase in the timely loss recognition after the adoption of IFRS. This may signal no change in the FRQ. This result does not support the second hypothesis which states that "Firms adopting IFRS are more likely to recognize losses in a timely manner compared to firms adopting local GAAP".

\section{Value relevance}

Table 7 presents the degree of association between financial measures and stock prices. The adjusted $\mathrm{R}^{2}$ for firms in the post-IFRS, 0.30866 , is larger than that of pre-IFRS, 0.232839 . This indicates that the financial reporting data is more value relevant in the post-IFRS compared to the pre-IFRS period which increases FRQ under IFRS. Focusing on the regression coefficients, it is clear that all variables increase their influence on the share price in the post-IFRS period. In the pre-IFRS period, the regression coefficient of earnings per share $(\beta 1)$ and the interaction variable (B3) are significant at 0.01 level. In the postIFRS period, all regression coefficients increased in magnitude and are significant. This indicates that all variables increase their influence on stock prices in the post-IFRS period. However, the chow F-statistic shows no significant difference between the regression coefficients in the post and preIFRS period. This indicates that there is no significant difference in value relevance after adopting IFRS which is consistent with the previous result. This result does not support the third hypothesis which states that "Firms adopting 
IFRS are more likely to have value relevant accounting information compared to firms adopting local GAAP”.

Table 7. Comparison of the pre-IFRS and post-IFRS Value relevance

\begin{tabular}{|l|c|c|}
\hline Value Relevance & Pre-IFRS (N=1278) & Post-IFRS (N=913) \\
\hline & $\beta 1=0.815968 \#$ & $\beta 1=1.336180 \#$ \\
The degree of association & $B 2=0.002505$ & $B 2=0.041822 \#$ \\
between financial measures & $B 3=-1.660291 \#$ & $B 3=-2.231037 \#$ \\
and stock prices. & $B 4=0.048866$ & $B 4=-0.119618 \# \#$ \\
& Adjusted $\mathrm{R}^{2}=0.232839$ & Adjusted $\mathrm{R}^{2}=0.308661$ \\
\hline
\end{tabular}

The symbols \#, \#\#, \#\#\# indicate significantly different from 0 at the $0.01,0.05$ and 0.1 level respectively.

The above results support the argument that IFRS reduces earning management. In addition, they do not support the argument that firms adopting IFRS are more likely to recognize losses in a timely manner nor more likely to have value relevant accounting information than firms adopting local GAAP. In other words, the results suggest some improvement in FRQ under IFRS. This study result is consistent with the findings of the study of Zhou et al. (2009) who find that firms adopting IFRS are less likely to smooth earnings than firms adopting Chinese GAAP. In addition, they didn't find adopting firms engaging in a more timely loss recognition which is consistent with Kwon et al. (2017), who documents lower earnings management in Korea after IFRS adoption, and Wu et al. (2017), who find that adopting IFRS in Taiwan does not lead to further increases in value relevance of financial reporting. The results support the findings of many other studies such as Eccher and Healy (2000), Van der Meulen et al. (2007) and Lin et al. (2012).

At the same time, this study result is inconsistent with the findings of ChingChieh et al. (2012), who finds that firms adopting IFRS in Taiwan are more value relevant, Mousa and Desoky (2014) who find some improvement in the value relevance after the adoption of IFRS and Capkun et al. (2016), who find an increase in earning management after mandatory IFRS adoption. The results are also inconsistent with the findings of many other studies such as Liu et al. (2011), Khanagha (2011) and Adibah Wan Ismail et al. (2013). One possible reason for the above results is that the stakeholders are affected not only by standards applied but also by other factors. Another possible reason is the characteristics of the emerging markets which might hinder the benefits from IFRS adoption as the weak corporate governance, inadequate shareholder protection and the lack of effective controls and infrastructure to oversight reporting under the IFRS. In addition, convergence in a country that has high-quality accounting standards may not significantly improve all the measures of the financial reporting quality.

\section{Conclusions}

The current study extends the literature on the effect of IFRS on financial reporting quality and examines three attributes namely: value relevance, timely 
loss recognition, and earnings management. It sheds the light on the role of IFRS in emerging markets to provide more evidence of the impact on the quality of financial information. The results show that firms in the post-IFRS period (20122014) are less likely to use accruals to smooth earnings compared to the pre-IFRS period (2008-2010). However, there is no significant difference in the timely loss recognition or the value relevance of accounting information under IFRS. The results suggest some improvement in FRQ under IFRS. This indicates that adopting high-quality accounting standards is not enough to guarantee improvement in FRQ.

This study is subject to several limitations. First, the study sample is limited to the industrial sector. It could be expanded by examining other sectors. Second, only three measures of FRQ are investigated. Further studies can be conducted using other measures as earnings persistence, loss avoidance, and investor responsiveness. The results imply the importance of IFRS and thus have direct implications for practitioners, international standard setters, and regulators. In addition, the results are of interest to analysts and investors who need to understand IFRS and FRQ issues in emerging markets.

\section{Acknowledgments}

Our thanks to "Professor Lela Pumphrey", Professor of Accounting in The British University in Egypt, for proofreading this research.

\section{References}

Adibah Wan Ismail W, Anuar Kamarudin K, Van Zijl T, Dunsta NK (2013) Earnings Quality and the Adoption of IFRS-based Accounting Standards: Evidence from an Emerging Market. Asian Review of Accounting 21(1): 53-73. DOI= https://doi.org/ $10.2139 /$ ssrn. 1566634 .

Ahmed AS, Neel M, Wang D (2013) Does Mandatory Adoption of IFRS Improve accounting Quality? Preliminary Evidence. Contemporary Accounting Research 30(4): 1344-1372. DOI= https://doi.org/10.2139/ssrn.1502909.

Aljifri K, Khasharmeh H (2006) An Investigation into the Suitability of the International Accounting Standards to the United Arab Emirates Environment. International Business Review 15(5): 505-526. DOI= https://doi.org/10.1016/j.ibusrev.2006.05. 009.

Ames D (2013) IFRS Adoption and Accounting Quality: The Case of South Africa. Journal of Applied Economics and Business Research 3(3): 154-165.

Armstrong CS, Barth ME, Jagolinzer AD, Riedl EJ (2010) Market Reaction to the Adoption of IFRS in Europe. The Accounting Review 85(1): 31-61. DOI= https://doi. org/10.2308/accr.2010.85.1.31.

Arum EDP (2013) Implementation of International Financial Reporting Standards (IFRS) and the Quality of Financial Statement Information in Indonesia. Research Journal of Finance and Accounting 4(19): 200-209. 
Ball R (1995) Making Accounting more International: Why, how, and how far will it go? Journal of Applied Corporate Finance 8(3): 19-29. DOI= https://doi.org/10.1111/ j.1745-6622.1995.tb00633.x.

Ball R, Kothari S, Robin A (2000) The Effect of International Institutional Factors on Properties of Accounting Earnings. Journal of Accounting and Economics 29(1): 151. DOI= https://doi.org/10.2139/ssrn.176989.

Ball R, Shivakumar L (2005) Earnings Quality in UK Private Firms: Comparative Loss Recognition Timeliness. Journal of Accounting and Economics 39(1): 83-128. DOI= https://doi.org/10.1016/j.jacceco.2004.04.001.

Barth ME, Clinch G, Shibano T (1999) International Accounting Harmonization and Global Equity Markets. Journal of Accounting and Economics 26(1-3): 201-235. DOI=https://doi.org/10.1016/s0165-4101(98)00038-x.

Barth ME, Landsman WR, Lang MH (2008) International Accounting Standards and Accounting Quality. Journal of Accounting Research 46(3): 467-498. DOI= https:// doi.org/10.2139/ssrn.688041.

Basu S (1997) The Conservatism Principle and the Asymmetric Timeliness of Earnings. Journal of Accounting and Economics 24(1): 3-37. DOI= https://doi.org/10.1111 /j.1911-3846.2011.01151.x.

Bekaert G, Harvey C (2017) Emerging Equity Markets in a Globalizing World. SSRN Electronic Journal. DOI= https://doi.org/10.2139/ssrn.2344817.

Benyasrisawat P (2011) Earnings Persistence, Value Relevance, and Earnings Timeliness: The Case of Thailand. Durham University.

Bradshaw M, Miller G (2002) Are Detailed Accounting Standards Sufficient to Ensure Compliance? Evidence from non-US firms adopting US GAAP. SSRN Electronic Journal. DOI= https://doi.org/10.2139/ssrn.310421.

Capkun V, Collins D, Jeanjean T (2016) The Effect of IAS/IFRS Adoption on Earnings Management (smoothing): A Closer Look at Competing Explanations. Journal of Accounting and Public Policy, 35(4): 352-394. DOI= https://doi.org/10.1016/j.jacc pubpol.2016.04.002.

Chalmers K, Clinch G, Godfrey JM (2011) Changes in Value Relevance of Accounting Information upon IFRS Adoption: Evidence from Australia. Australian Journal of Management 36(2): 151-173. DOI= https://doi.org/10.1177/0312896211404571.

Chan ALC, Hsu AWH, Lee E (2015) Mandatory Adoption of IFRS and Timely Loss Recognition across Europe: The Effect of Corporate Finance Incentives. International Review of Financial Analysis, 38: 70-82. DOI= https://doi.org/10.1016/ j.irfa.2015. 02.002.

Chen JT, Yeh YH (2002) The Relationship between Corporate Restructuring, Corporate Governance and Earnings Management. International Journal of Accounting Studies 34: $1-29$.

Ching-Chieh L, Chi-Yun H, Wen-Hsiang L, Wen-Chih L (2012) IFRS Adoption and financial Reporting Quality: Taiwan Experience. Source: International Journal of Academic Research in Accounting, Finance and Management Sciences 2(4): 283292.

Christensen HB, Lee E, Walker M, Zeng C (2015) Incentives or Standards: What Determines Accounting Quality Changes around IFRS Adoption? European Accounting Review 24(1): 31-61. DOI= https://doi.org/10.2139/ssrn.1013054.

Clarkson P, Hanna JD, Richardson GD, Thompson R (2011) The Impact of IFRS Adoption on the Value Relevance of Book Value and Earnings. Journal of Contemporary Accounting \& Economics 7(1): 1-17. DOI= https://doi.org/10.1016/j. jcae.2011.03. 001. 
Coelho AC, Galdi FC, Lopes AB (2017) Determinants of Asymmetric Loss Recognition Timeliness in Public and Private Firms in Brazil. Emerging Markets Review 31: 6579. DOI= https://doi.org/10.1016/j.ememar.2017.02.002.

Collins D, Pincus M, Xie H (1999) Equity Valuation and Negative Earnings: The Role of Book Value of Equity. The Accounting Review 74(1): 29-61.

COMMISSION, FS (2018) Taiwan's International Financial Competitiveness [Online]. Available: https://www.fsc.gov.tw/en/home.jsp?id=27\&parentpath=0,6.

Dayanandan A, Donker H, Ivanof M, Karahan G (2016) IFRS and Accounting Quality: Legal Origin, Regional, and Disclosure Impacts. International Journal of Accounting and Information Management 24(3): 296-316. DOI= https://doi.org/10.1108/ijaim11-2015-0075.

Dechow P, Ge W, Schrand C (2010) Understanding Earnings Quality: A Review of the Proxies, their Determinants and their Consequences. Journal of Accounting and Economics 50(2-3) 344-401. DOI= https://doi.org/10.2139/ssrn.1485858.

Devalle A, Onali E, Magarini R (2010) Assessing the Value Relevance of Accounting Data after the Introduction of IFRS in Europe. Journal of International Financial Management \& Accounting 21(2): 85-119. DOI= https://doi.org/10.2139/ssrn.24207 65.

Eccher EA, Healy PM (2000) The Role of International Accounting Standards in Transitional Economies: A Study of the People's Republic of China. SSRN Electronic Journal. DOI=https://doi.org/10.2139/ssrn.233598.

Florou A, Pope PF (2012) Mandatory IFRS Adoption and Institutional Investment Decisions. The Accounting Review 87(6): 1993-2025. DOI= https://doi.org/10.2139 /ssrn.1362564.

Francis J, Lafond R, Olsson PM, Schipper K (2004) Costs of Equity and Earnings Attributes. The Accounting Review 79(4): 967-1010. DOI= https://doi.org/10.2308 /accr.2004.79.4.967.

Houqe MN, Van Zijl T, Dunstan K, Karim AW (2012) The Effect of IFRS Adoption and Investor Protection on Earnings Quality around the World. The International Journal of Accounting 47(3): 333-355. DOI= https://doi.org/10.2469/dig.v43.n1.1.

Huang RD, Shiu CY (2009) Local Effects of Foreign Ownership in an Emerging Financial Market: Evidence from Qualified Foreign Institutional Investors in Taiwan. Financial Management 38(3): 567-602. DOI= https://doi.org/10.1111/j.1755-053x.2009.0104 8.x.

Iatridis G (2010) International Financial Reporting Standards and the Quality of Financial Statement Information. International Review of Financial Analysis 19(3): 193-204. DOI= https://doi.org/10.1016/j.irfa.2010.02.004.

Irvine HJ, Lucas N (2006) The Rationale and Impact of the Adoption of International financial Financial Reporting Standards on Developing Nations: The Case of the United Arab Emirates, in Proceedings of the $18^{\text {th }}$ Asian-Pacific Conference on International Accounting Issues, Maui, Hawaii, 15-18 October 2006, 1-22 Available at https://ro.uow.edu.au/cgi/viewcontent.cgi?referer=https://www.google.com/\&http sredir $=1 \&$ article $=1230 \&$ context $=$ commpapers.

Istrate C, Georgescu IE, Carp M, Robu IB, Pavaloaia L (2015) Accruals Earnings Management in Emerging Markets under the Transition to IFRS: The Case of Romanian Listed Companies. Transformations in Business \& Economics 14(2A): 393-411.

Jeanjean T, Stolowy H (2008) Do Accounting Standards Matter? An Exploratory Analysis of Earnings Management before and after IFRS Adoption. Journal of Accounting and 
Public Policy 27(6): 480-494. DOI= https://doi.org/10.1016/j.jaccpubpol.2008.09. 008.

Kaaya I (2015) The International Financial Reporting Standards (IFRS) and Value Relevance: A Review of Empirical Evidence. Journal of Finance and Accounting 3(3): 37-46.

Karampinis N, Hevas D (2009) The Effect of the Mandatory Application of IFRS on the Value Relevance of Accounting Data: Some Evidence from Greece. European Research Studies 12(1): 73-100.

Khanagha JB (2011) International Financial Reporting Standards (IFRS) and Value Relevance of Accounting Information: Evidence from Bahrain and United Arab Emirates Stock Markets. African Journal of Social Sciences 1: 101-114.

Kwon SY, Na K, Park J (2017) The Economic Effects of IFRS Adoption in Korea. AsiaPacific Journal of Accounting \& Economics 1-41. DOI= https://doi.org/10.1080/160 81625.2017.1298454.

Lang M, Raedy JS, Wilson W (2006) Earnings Management and Cross Listing: Are Reconciled Earnings Comparable to US Earnings? Journal of Accounting and Economics 42(1-2): 255-283. DOI= https://doi.org/10.1016/j.jacceco.2006.04.005.

Li S (2010) Does Mandatory Adoption of International Financial Reporting Standards in the European Union Reduce the Cost of Equity Capital? The Accounting Review 85(2): 607-636. DOI= https://doi.org/10.2139/ssrn.1113353.

Lin S, Riccardi W, Wang C (2012) Does Accounting Quality Change following a Switch from US GAAP to IFRS? Evidence from Germany. Journal of Accounting and Public Policy 31(6): 641-657. DOI= https://doi.org/10.1016/j.jaccpubpol.2012.10. 006.

Liu C, Yao LJ, Hu N, Liu L (2011) The Impact of IFRS on Accounting Quality in a Regulated Market: An Empirical Study of China. Journal of Accounting, Auditing \& Finance 26(4): 659-676.

Meeks G, Swann GP (2009) Accounting Standards and the Economics of Standards. Accounting and Business Research 39(3): 191-210. DOI= https://doi.org/10.1080/ 00014788.2009 .9663360$.

Morais AI, Curto JD (2008) Accounting Quality and the Adoption of IASB Standards: Portuguese Evidence. Revista Contabilidade \& Finanças 19(48): 103-111. DOI= https://doi.org/10.1590/s1519-70772008000300009.

Mousa GA, Desoky AM (2014) The Value Relevance of International Financial Reporting Standards (IFRS): The Case of the GCC Countries. Journal of Accounting, Finance and Economics 4(2): 16-28.

Myers JN, Myers LA, Skinner DJ (2007) Earnings Momentum and Earnings Management. Journal of Accounting, Auditing \& Finance 22(2): 249-284. DOI= https://doi.org/10. 2139/ssrn.741244.

Nulla YM (2014) Does IFRS Adoption Influence Quality of Reporting?: An Empirical Evidence from Large Canadian Banks. International Journal 2(2): 85-109.

Ohlson JA (1995) Earnings, Book Values, and Dividends in Equity Valuation. Contemporary Accounting Research 11(2): 661-687. DOI= https://doi.org/10.1111/j. 1911-3846.1995.tb00461.x.

Outa ER (2011) The Impact of International Financial Reporting Standards (IFRS) Adoption on the Accounting Quality of listed Companies in Kenya. International Journal of Accounting and Financial Reporting 1(1):212-241. DOI= https://doi.org/ 10.5296/ijafr.v1i1.1096. 
Paananen M, Lin H (2009) The Development of Accounting Quality of IAS and IFRS over Time: The Case of Germany. Journal of International Accounting Research 8: 31-55. DOI= https://doi.org/10.2139/ssrn.1066604.

Paglietti P (2010) Earnings Management, Timely Loss Recognition and Value Relevance in Europe following the IFRS Mandatory Adoption: Evidence from Italian listed Companies. Economia Aziendale Online 1(4): 97-117.

Palacios Manzano M, Martinez Conesa I (2014) Assessing the Impact of ifrs Adaptation on Earnings Management: An Emerging Market Perspective. Transformation in Business \& Economics 13(1(31)): 21-40.

Peng H, Chen MH (2014) A Comparison of the Value Relevance of IFRS with Taiwanese GAAP Accounting Information. Journal of International Accounting Reseach (JIAR) Conference, 2014. Available at https://af.polyu.edu.hk/media/7237/518_fi nal.pdf.

Rudra T, Bhattacharje ECD (2012) Does IFRs influence Earnings Management? Evidence from India. Journal of Management Research 4(1): 1-13. DOI= https://doi.org/10. 5296/jmr.v4i1.849.

Van Der Meulen S, Gaeremynck A, Willekens M (2007) Attribute differences between US GAAP and IFRS Earnings: An Exploratory Study. The International Journal of Accounting 42(2): 123-142. DOI= https://doi.org/10.2139/ssrn.874923.

Van Tendeloo B, Vanstraelen A (2005) Earnings Management under German GAAP versus IFRS. European Accounting Review 14(1): 155-180. DOI= https://doi.org/10. 1080/0963818042000338988.

Verdi RS (2006) Financial Reporting Quality and Investment Efficiency. DOI= https://doi. org/10.2139/ssrn.930922.

Wong TJ, JIAN M (2003) Earnings Management and Tunneling through related Party Transactions: Evidence from Chinese Corporate Groups. SSRN Electronic Journal. DOI= https://doi.org/10.2139/ssrn.424888.

Wu TC, Hsieh WT, Yu CC, Chu HT (2017) Value Relevance of Financial Statements in Convergence with IFRS: Analyses in the Abnormal Pricing Error Method. Applied Economics Letters 24(7): 490-493. DOI= https://doi.org/10.1080/13504851.20196. 1205714.

Yoon S (2007) Accounting Quality and International Accounting Convergence, Oklahoma State University. DOI= https://doi.org/10.21073/kiar.2011..37.011.

Zéghal D, Chtourou S, Sellami YM (2011) An Analysis of the Effect of Mandatory Adoption of IAS/IFRS on Earnings Management. Journal of International Accounting, Auditing and Taxation 20(2): 61-72. DOI= https://doi.org/10.1016/j. intaccaudtax. 2011.06.001.

Zhou H, Xiong Y, Ganguli G (2009) Does the Adoption of International Financial Reporting Standards restrain Earnings Management? Evidence from an Emerging Market. Academy of Accounting \& Financial Studies Journal, 13: 43-56. Available: https://www.abacademies.org/journals/academy-of-accounting-and-financial-studiesjournal-home.html. 